\title{
28 Research Suare \\ Immune checkpoint inhibitors use and effects on prognosis of COVID-19 infection: A systematic review and meta-analysis
}

\author{
Wenwei Qian \\ Medical School of Southeast University \\ Ying Ye \\ Affiliated Hospital of Xuzhou Medical College \\ Lugen Zuo \\ First Affiliated Hospital of Bengbu Medical College \\ Ting Song \\ The Sixth People's Hospital of Qingdao \\ Qing Xu \\ Tongji University \\ Yinghong Wang \\ The University of MD Anderson Cancer Center \\ Yun Tian ( $\square$ summer.cloud@live.cn ) \\ Tongji University
}

\section{Systematic Review}

Keywords: Immune checkpoint inhibitor, COVID-19, Prognosis, Meta-analysis

Posted Date: September 23rd, 2020

DOI: https://doi.org/10.21203/rs.3.rs-82103/v1

License: (c) (i) This work is licensed under a Creative Commons Attribution 4.0 International License. Read Full License

Version of Record: A version of this preprint was published at Immunotherapy on August 25th, 2021. See the published version at https://doi.org/10.2217/imt2021-0007. 


\section{Abstract}

Background: The influence of prior exposure to immune checkpoint inhibitors (ICls) on the coronavirus disease 2019 (COVID-19) infection remains unknown.

Methods: We searched the PubMed, Embase, and Web of Science databases from the inception of each database through August 8, 2020. We included studies that reported ICI use in cancer patients and their prognosis in the context of COVID-19. Raw data from the included studies were pooled to determine effect estimates. Chi-squared and $\mathrm{I}^{2}$ tests were used to calculate heterogeneity among the included studies.

Results: Eighteen studies were included for the systematic review, and 8 of those were included in the meta-analysis. Patients with prior ICI treatment exhibited a higher rate of hospitalization (OR [odds ratio] 2.6, 95\% Cl 1.45-4.68, $\mathrm{p}=0.001 ; \mathrm{l}^{2}=0 \%$ ) and severe disease $(\mathrm{OR} 1.98,95 \% \mathrm{Cl} 1.14-3.43, \mathrm{p}=0.015)$. However, the OR of mortality in ICl-exposed cases was similar to non-ICl exposed patients (OR $0.90,95 \% \mathrm{Cl} 0.60-1.34, p=0.60 ; I^{2}=49 \%$ ). No statistically significant difference in mortality was observed between patients exposed to $\mathrm{ICl}$ and other antitumor treatments.

Conclusions: Although a higher rate of hospitalization and severe disease was observed, prior exposure to ICI did not significantly increase the rate of death in the context of COVID-19.

\section{Introduction}

Coronavirus disease 2019 (COVID-19) has already quickly spread on a global scale, evolving into a pandemic and threatening global health (1, 2). The rapid rise of the disease, and the resultant hospitalizations and deaths have strained public health systems (3). In addition to lung injury, COVID-19 is associated with hepatitis, gastrointestinal symptoms, such as diarrhea, and damage to other organs (4). However, there currently are no effective therapies for its treatment. Cancer patients are more vulnerable due to the tumor itself and anticancer treatment $(5,6)$. It remains to be seen whether the application of anticancer drugs results in differential prognoses for patients infected with COVID-19. It is critically important for clinicians to identify risk factors associated with severity and mortality and take appropriate interventions.

Currently, immunotherapy has raised major concerns amid different therapeutic strategies in cancer treatment, due to its intrinsic and extensive influence on the immune system (7). Immunotherapy primarily consists of several immune checkpoint inhibitors (ICls), including inhibitors targeting the cytotoxic Tlymphocyte-associated protein 4 (CTLA-4), programmed cell death protein 1 (PD-1), and programmed death-ligand 1 (PD-L1). Anti-CTLA-4 and anti-PD-1/-PD$\mathrm{L} 1$ antibodies reactivate cytotoxic CD8+ T cells for antitumor activity through targeting T-cell exhaustion pathways (8). In patients with malignancy, ICI sometimes induces adverse events, including liver injury, pneumonia, and colitis (9). Given the convergence of the downstream effects on innate immunity and organ damage caused by both ICl and COVID-19 infections, we investigated whether patients present worse prognosis due to prior exposure to ICls.

Given that ICI therapy represents an important treatment choice for some patients, whether ICI has an impact on the prognosis of COVID-19 infection in cancer patients should be elucidated. However, whether COVID-19 patients receiving ICl are prone to poorer prognosis remains unknown. This systematic review and meta-analysis aimed to assess the safety of ICl application in COVID-19 patients and to make reasonable recommendations by reviewing available publications.

\section{Methods}

\subsection{Search strategy}

We searched the PubMed, Embase, and Web of Science databases, limiting our search to papers written in English from the inception of each database until August 8, 2020. Key words used for the search were "severe acute respiratory syndrome coronavirus 2", "SARS-CoV-2", "2019-nCoV", "COVID-19", "Cancer", "Melanoma”, "Malignancy”, "Tumor”, “Immune checkpoint inhibitors”, “PD-1", “CTLA-4", and "Immunotherapy”. Articles were also retrieved by screening the reference lists of included studies and from related review papers. One reviewer (Y.T.) with experience in database searches designed the search, and 2 reviewers (W.Q., Y.T.) independently screened the titles, abstracts, and full text according to these eligibility criteria, assessing the eligibility of publications.

\subsection{Inclusion criteria}

We included randomized controlled trials (RCTs), observational studies, case series, and case reports that reported ICl use in cancer patients and their prognosis in the context of COVID-19. Exclusion criteria were as follows: (1) the same patients enrolled in different studies and (2) studies such as clinical reviews, editorials, letters, or erratum that did not report original data. When data was inadequate in some studies, attempts were made to contact the investigators for the missing data.

\subsection{Data extraction and definitions}

Two researchers (W.Q., Y.T.) independently extracted data from the included studies in a double-blinded manner. Any disagreements were resolved by a third investigator (L.Z.) or by consensus. The following variables was extracted: name of first author, country, date of COVID-19 diagnosis, study type, age, gender, number of total patients, number of patients receiving ICI, treatment interval before diagnosis of COVID-19, treatment and cancer type, and outcome of infection, such as hospitalization and/or severity and/or mortality (Table 1). Severe disease was defined according to the original studies, primarily based on the symptoms present during treatment-e.g., admission to the intensive care unit (ICU), development of severe or critical symptoms, and utilization of 
invasive mechanical ventilation (5). To ensure high-quality evidence, this study was performed in accordance with the Preferred Reporting Items of Systematic Reviews and Meta-analysis (PRISMA) statement.

\subsection{Quality assessment}

The Newcastle-Ottawa Scale (NOS) was used for observational studies to evaluate the methodological quality of the original study (Table 1). The risk of bias was independently assessed by two authors (W.Q., Y.T.). The NOS consists of eight criteria and produces scores ranging from 0 to 9 . Studies with NOS scores of $>7$ were regarded as high quality.

\subsection{Data synthesis and statistical analysis}

All statistical analyses in this study were performed using R (version 4.0.2). Odds ratios (OR) were used to describe the ratio of the probability of events occurring in cancer patients treated with different therapies. The Chi-squared and $\mathrm{I}^{2}$ tests were used to calculate heterogeneity among the included studies. $\mathrm{P}<0.05$ or $\mathrm{I}^{2}>50 \%$ indicated substantial heterogeneity across the articles (10), and a random-effects model was used (11). Otherwise, the fixed-effects model was used. Publication bias was examined by funnel plots and evaluated by Egger's regression test (12) if applicable. A p<0.05 was considered statistically significant.

\section{Results}

\subsection{Search results}

The search strategy identified 1619 articles. Among these studies, 890 were duplicates. After screening the title and abstract, 1556 were excluded, and the full text of the remaining 63 articles was reviewed. Among these, 18 studies reported ICl use in cancer patients and prognosis of COVID-19 infection (5, 13-29). The 18 articles consisted of 9 cohort studies, 5 case series and 4 case reports. These 18 studies were included for review. Finally, 8 of these studies were eligible for the meta-analysis, excluding studies containing less than four ICl patients.

\subsection{Patient characteristics}

Patient characteristics of the included studies are shown in Table 1. The studies were from eight countries, including Belgium ( $n=1)$, China ( $n=2)$, Germany $(n=2)$, Italy $(n=6)$, Spain $(n=2)$, the United Kingdom $(n=3)$, the United States $(n=5)$, and Turkey $(n=1)$. Eight of these studies included more than three ICI users, and the median age of study participants was 64 to 69 years old. Of these 8 studies, clinical outcomes were defined as hospitalization in four studies, severity in six studies, and mortality in seven studies (Table 1). However, there was nonuniformity in the criterion of the time interval from last dose to COVID-19 diagnosis (13-19) (Table 1). Results of the quality assessment of the included studies assessed by NOS scores are presented in Table 1.

\subsection{ICl use and risk of hospitalization in COVID-19 patients}

We combined 4 studies $(13,15,17,18)$ reporting the hospitalization of COVID-19 infection in patients on ICI treatment, and the pooled estimate of the rate of hospitalization was $0.67(95 \% \mathrm{Cl} 0.54-0.77)$, and no heterogeneity was observed among these studies $\left(I^{2}=0 \%, p=0.75 ;\right.$ Figure 2$)$. Three $(13,15,17)$ of the 4 studies contained hospitalization information of patients without ICl exposure. The proportion of hospitalization was markedly increased in patients treated with ICl therapy compared to those without ICl treatment (OR 2.60 [95\% $\mathrm{Cl} 1.45-4.68], p=0.001 ; I^{2}=0 \%$; Figure 3 ). Publication bias was not evaluated due to the small number of included studies.

\subsection{ICl use and influence on COVID-19 severity}

Six studies $(5,13,15,17-19)$ that included 79 COVID-19 cases with ICl exposure reported on COVID-19 severity in relation to ICI exposure. The combined proportion of severe disease was 0.4 (95\% Cl 0.30-0.51, $\mathrm{I}^{2}=0 \%$; Figure 2 ). Out of these 6 studies, four studies $(5,13,15,17)$ included 64 COVID-19 cases with ICl exposure and 650 COVID-19 cases unexposed to ICl. The pooled OR of COVID-19 severity was 1.98 (95\% Cl, 1.14-3.43, p=0.02; Figure 3). Moderate heterogeneity was observed among the studies $\left(I^{2}=35 \% ; p=0.20\right)$. Publication bias was not evaluated due to the small number of included studies.

\subsection{ICl use and risk of mortality in COVID-19 patients}

The overall analysis included 7 studies $(5,13-16,18,19)$. Together, 148 COVID-19 cases with ICI exposure and 1850 COVID-19 cases without ICl exposure were included. The pooled proportion of mortality in COVID-19 patients with $\mathrm{ICl}$ exposure was $0.26\left(95 \% \mathrm{Cl}, 0.20-0.34 ; \mathrm{I}^{2}=0 \%\right.$; Figure 2). Next, the risk associated with $\mathrm{ICl}$ use and mortality was assessed. Overall, the OR of mortality in ICl-exposed cases was similar to non-ICl exposed COVID-19 patients (OR 0.90, 95\% CI 0.60- 
1.34, $p=0.60$; Figure 3). Moderate heterogeneity was observed among the studies $\left(I^{2}=49 \% ; p=0.10\right)$. Publication bias was not observed by funnel plot (Figure s1) or Egger test $(p=0.14)$ for mortality.

We further examined the mortality between exposure to ICl and other treatments in cancer patients in the context of COVID-19. However, we did not identify significant differences between ICl and chemotherapy (OR 1.06, 95\% Cl 0.67-1.67, $p=0.80 ; I^{2}=3 \%$; Figure 4A), hormone therapy (OR 1.26, 95\% Cl 0.44-3.59, $p=$ $0.67 ; I^{2}=59 \%$; Figure 4B), radiotherapy (OR 1.44, 95\% Cl 0.67-3.07, $p=0.35 ; I^{2}=46 \%$; Figure 4C), $\quad$ surgery $\left(\mathrm{OR} 1.21,95 \% \mathrm{Cl} 0.50-2.98, p=0.67 ; I^{2}=0 \% ;\right.$ Figure $4 D$ ), or targeted therapy (OR 1.53, 95\% Cl 0.89-2.63, $p=0.13 ; I^{2}=0 \%$; Figure 4E).

\subsection{Temporal relationship between prior ICl receipt and diagnosis of COVID-19}

Given that the receptor can be occupied for months (30) and the initial start of ICI therapy results in a distinct proliferative burst (31-34), different intervals from the last dose of ICI to the diagnosis of COVID-19 may theoretically influence the prognosis of COVID-19 infection. Luo et al (15) defined five categories of prior PD-1 blockade, including no prior PD-1, ever received PD-1 blockade, last receipt within 6 months, last receipt within 6 weeks, and first receipt within 3 months, detecting the outcomes of interest. Overall, there was no significant difference in prognosis regardless of PD- 1 blockade exposure. We extracted data from this study and regrouped patients according to intervals from last dose of ICl to the diagnosis of COVID-19: no prior PD-1, interval > 6 months, interval between 6 months and 6 weeks, interval < 6 weeks and initial dose within 3 months (Figure 5). However, we did not capture any statistically significant differences between no prior PD-1 group and the other four groups tested by Chi-square test or Fisher's exact test in terms of prognosis, including hospitalization, severe disease and mortality (Figure 5). Consistent with the above outcomes, Wu et al (19) observed a similar risk of severity in different intervals from the last ICl administration to COVID-19 diagnosis (interval $\geq 28$ days vs. interval $<28$ days, $p=1.00$ ).

\subsection{ICl-induced lung injury and COVID-19 infection}

ICl-induced pneumonitis presents similar clinical and radiological features to COVID-19, challenging the early diagnosis of COVID-19 (20). Guerini et al (23) and Lovly et al (24) reported two cases that experienced misdiagnosis caused by ICl-induced pneumonitis who died due to uncontrolled COVID-19 infection. Clinicians should always consider COVID-19 as a differential diagnosis, as few places were spared during the pandemic. In another report (35), 2 patients were initially highly suspected of COVID-19 infection based on clinical manifestations, imaging findings, and epidemiology. Steroids were withheld in one of them, and the disease became worse until a third CT scan was obtained and a second negative RT-PCR test was released after admission. Both patients were eventually diagnosed with ICl-induced pneumonitis, and a mean delay of 3 days in steroid initiation was attributed to the COVID-19 pandemic.

Except for missed window of optimal treatment caused by delayed diagnosis, ICl-induced pneumonitis itself reduces patient resistance and exacerbates COVID-19 infection. Here, we were curious about the influence of ICl in lung cancer patients infected with COVID-19. Data showed that ICI application did not significantly influence the severity of COVID-19 in lung cancer patients (ICl application [7/12] vs. no ICl application [8/23], p= 0.181) (17). Consistently, ICI exposure in lung cancer patients did not exhibit a higher risk for developing severity than in patients with other solid cancers (lung cancer [7/12] vs. other solid cancers [5/19], $\mathrm{p}=0.13)(17)$.

\section{Discussion}

This review included 18 articles that encompassed $220 \mathrm{ICl}$ users infected with COVID-19. Findings suggest that ICl application does not increase mortality among cancer patients infected with COVID-19; however, it did result in increased hospitalizations and severe infections. In addition, different intervals from the last dose of ICI to diagnosis of COVID-19 might not influence the prognosis of COVID-19 infection. Finally, given the unpredictable duration of the pandemic, we should always keep in mind a differential diagnosis of COVID-19 and rational adjustment of ICI use.

Patients with cancer are theoretically more vulnerable to infection due to poor health status and immunosuppressive conditions provoked by both the cancer and antitumor therapies (36-39). Poorer prognosis in COVID-19 infection has been associated with several factors, including older age, gender, and comorbidities such as pulmonary disease, cardiac disease, hypertension, and cancer $(16,40)$. Liang et al collected and analyzed 1590 cases from 575 hospitals (41). In their study, 18 of 1590 (1\%; 95\% Cl 0.61-1.65) COVID-19 cases had a history of cancer, which was higher than the overall incidence of cancer in the population (285.83 [0.29\%] per 100000 people). Importantly, patients with cancer exhibited a higher rate of severe disease than patients without cancer (7/18 (39\%) vs. 124/1572 (8\%), p=0.0003). In a study from America(17), 423 patients with cancer were diagnosed with COVID-19. Among them, 40\% were hospitalized for COVID-19, 20\% developed severe respiratory illness and 12\% died. While in Europe, Pinato et al reported a high mortality (33.6\%) in a multicenter study, reflecting serious strains to the public health system (16). We here pooled the prognostic data from COVID-19-infected cases with prior exposure to ICl. The rate of hospitalization was $67 \%, 42 \%$ developed severe disease and $26 \%$ died.

Physicians worry about the influence of ICl administration on COVID-19 infection for two main reasons (42). The first is the potential overlap between the two lung injuries: possible pneumological toxicity from ICI use and COVID-19 pneumonia. The incidence of ICl-related pneumonitis was reported to be $2.5-5 \%$ with anti-PD-1/PD-L1 monotherapy and 7-10\% with anti-CTLA-4/anti-PD-1 combination therapy (43). This fatal immune-related adverse events (irAEs) accounted for $35 \%$ of treatment-related deaths (44). The second concern is the potential synergy between ICI mechanisms and COVID-19 pathogenesis, both of which are involved in immune hyperactivation (45-47). Elizabeth V. Robilotti et al (17) identified prior ICl exposure as an independent risk factor for hospitalization (OR $2.84,95 \% \mathrm{Cl} 1.24-6.72, \mathrm{p}=0.013)$ and severe disease (HR 2.74, 95\% $\mathrm{Cl} 1.37-5.46, \mathrm{p}=0.004)$. Some studies reported negative effects of ICl on mortality (13).

Page 4/16 
However, most of these studies did not observe statistically significant differences with respect to ICI on the prognosis of COVID-19 infection (5, 14-16). Integrating multiple studies into the present study, we found that prior receipt of ICl significantly increased the rate of hospitalization and severe disease. In contrast, there was no significant difference in mortality among patients with or without prior ICl exposure (OR 0.90, 95\% $\mathrm{Cl} 0.60-1.34, \mathrm{p}=0.60)(\mathrm{Figure} 3)$.

Most of the included studies focused on the impact of ICl use or not on the prognosis of COVID-19 $(5,13,14,16-18)$, but they did not take other important factors into consideration, including courses of ICl use, intervals from the last dose to the diagnosis of COVID-19, and the effect of the first dose. Wu et al (19) found that patients who received 3 or more cycles of ICI were more likely to develop severe COVID-19, albeit this difference was not statistically significant (6/7 [85.7\%] vs. $1 / 4$ [25\%], p=0.09). Additionally, they divided patients into 2 groups according to the most resent dose before diagnosis of COVID-19: > 28 days and $<28$ days, though no association was found between that time interval and disease severity (4/6 [66.7\%] vs. 3/5 [60\%], p=1.00). Another study (15) included 69 patients and defined 5 groups according to the interval from last ICI receipt to COVID-19 diagnosis: no prior PD-1, ever received PD-1, last receipt within 6 months, last receipt within 6 weeks, and first receipt within 3 months. Overall, there was no statistically significant difference in different groups in terms of the rate of hospitalization, severe disease or death.

As the influence of ICl on cancer patients infected with COVID-19 is not clear, there are no authoritative guidelines for ICI modifications in the context of COVID19. Modifications of drug application are often empirical and based on the mechanism of drug action, taking tumor treatment and epidemic prevention into account (48). Wang (49) et al suggested that administration of anticancer drugs should be changed from infusion to oral administration if available. For maintenance therapy, we could appropriately prolong the infusion intervals according to patient condition. Aeppli et al performed an online survey among physicians involved in the treatment of renal cell carcinoma (50). Compared to that outside the pandemic, the use of ipilimumab/nivolumab fell by half in intermediate/poor-risk patients during the pandemic ( $80 \%$ vs. $41 \%)$. In favorable risk patients, ICl-containing regimens were consistently chosen less often, and instead, more TKI monotherapies were prescribed. In patients responding to established ICI-containing therapies, most participants modified treatment regimen by extending cycle length. Another survey focused on patient perspective on oncological care (51). In patients with adjusted treatment, immunotherapy (32\%) was most frequently adjusted. Consistently, in patients with delay and discontinuation of treatment, immunotherapy (39\% and $33 \%)$ was the most frequently included modality.

This study has important implications for clinical practice. Given that the pandemic may last for another several months or even years, physicians should balance cancer treatment and COVID-19 infection. Our results indicate that ICl administration increases the rate of severe disease, though it did not significantly increase the rate of death in COVID-19-infected patients. This suggests that we should not easily postpone, suspend, or alter our established treatment decisions in clinical practice, especially for patients who are undergoing ICl-containing regimens, because ICI has irreplaceable performance in certain antitumor treatments (8). Delay or modification of therapy should be considered on a case-by-case basis (52).

This systematic review and meta-analysis has several limitations. The most important limitation is that we could not rule out unknown confounders. Previous studies reported that age, sex, smoking and comorbidities, including pulmonary disease, cardiac disease, and hypertension, significantly affect the prognosis of COVID-19 infection. However, these potential confounders were not considered in most of the included studies. Second, due to the relatively small number of studies, we were unable to evaluate the effects of $\mathrm{ICl}$ subclasses or their role in individual tumors. Additionally, the benefit of longer duration of ICl on the

overall survival (OS) has been determined, and frequent or early interruption of ICI has been proved to be associated with worse OS (8). It will be worthwhile to comment on the cancer outcome in this population. However, limited by a short follow-up period, we failed to assess the cancer outcome in patients who had delayed or interrupted ICI treatment through published studies. Further, studies on the association between irAEs and COVID-19 risk and outcome are needed. Lastly, included studies defined several intervals from the last dose to the diagnosis of COVID-19 infection, which may have influenced the findings.

In conclusion, the results of this meta-analysis suggest that, although a higher rate of hospitalization and severe disease was observed among patients who were undergoing ICl-containing regimens, prior exposure to ICI does not significantly increase the risk of COVID-19 mortality. Additionally, different intervals from last dose of ICl to the diagnosis of COVID-19 may not influence the prognosis of COVID-19 infection.

\section{Declarations}

Funding: This study was supported by Natural Science Foundation of Shanghai (Grant 19ZR1447100) and Foundation of Shanghai Dermatology Hospital (Grants 17HBDS08 and 2018KYQD02).

Contribution statements: Conception and design: Yun Tian, Wenwei Qian, and Ying Ye. Acquisition of data: Yun Tian, Wenwei Qian, Ying Ye, Lugen Zuo, and Ting Song. $\quad$ Analysis and interpretation of data: Wenwei Qian, Ying Ye, Lugen Zuo, and Yun Tian. Writing, review, and revision of the manuscript: Wenwei Qian, Yun Tian, Lugen Zuo, Qing Xu, and Yinghong Wang. Final approval of manuscript: All authors.

Acknowledgements: This study was supported by Natural Science Foundation of Shanghai (Grant 19ZR1447100) and Foundation of Shanghai Dermatology Hospital (Grants 17HBDS08 and 2018KYQD02).

Conflicts of interest: The authors declare no conflicts of interest 


\section{Abbreviations}

Cl: confidence interval; COVID-19: coronavirus disease 2019; CTLA-4: cytotoxic T-lymphocyte-associated protein 4; HR: hazard ratio; ICls: immune checkpoint inhibitors; ICU: intensive care unit; IQR: interquartile range; NOS: Newcastle-Ottawa Scale; OR: odds ratio; OS: overall survival; PD-1: programmed cell death protein 1; PD-L1: programmed death-ligand 1; PRISMA: Preferred Reporting Items of Systematic Reviews and Meta-analysis; RCTs: randomized controlled trials.

\section{References}

1. C.C. Lai, C.Y. Wang, Y.H. Wang, S.C. Hsueh, W.C. Ko, and P.R. Hsueh. Global epidemiology of coronavirus disease 2019 (COVID-19): disease incidence, daily cumulative index, mortality, and their association with country healthcare resources and economic status. International journal of antimicrobial agents. 55:105946 (2020).

2. Z. Wuand J.M. McGoogan. Characteristics of and Important Lessons From the Coronavirus Disease 2019 (COVID-19) Outbreak in China: Summary of a Report of 72314 Cases From the Chinese Center for Disease Control and Prevention. Jama(2020).

3. D.B. Jernigan. Update: Public Health Response to the Coronavirus Disease 2019 Outbreak - United States, February 24, 2020. MMWR Morbidity and mortality weekly report. 69:216-219 (2020).

4. A. Guptaand M.V. Madhavan. Extrapulmonary manifestations of COVID-19. 26:1017-1032 (2020).

5. M. Dai, D. Liu, M. Liu, F. Zhou, G. Li, Z. Chen, Z. Zhang, H. You, M. Wu, Q. Zheng, and Y. Xiong. Patients with Cancer Appear More Vulnerable to SARS-CoV2: A Multicenter Study during the COVID-19 Outbreak. 10:783-791 (2020).

6. V. Mehtaand S. Goel. Case Fatality Rate of Cancer Patients with COVID-19 in a New York Hospital System. 10:935-941 (2020).

7. Y. Yang. Cancer immunotherapy: harnessing the immune system to battle cancer. The Journal of clinical investigation. 125:3335-3337 (2015).

8. P. Darvin, S.M. Toor, V. Sasidharan Nair, and E. Elkord. Immune checkpoint inhibitors: recent progress and potential biomarkers. 50:1-11 (2018).

9. J.M. Michot, C. Bigenwald, S. Champiat, M. Collins, F. Carbonnel, S. Postel-Vinay, A. Berdelou, A. Varga, R. Bahleda, A. Hollebecque, C. Massard, A. Fuerea, V. Ribrag, A. Gazzah, J.P. Armand, N. Amellal, E. Angevin, N. Noel, C. Boutros, C. Mateus, C. Robert, J.C. Soria, A. Marabelle, and O. Lambotte. Immunerelated adverse events with immune checkpoint blockade: a comprehensive review. European journal of cancer. 54:139-148 (2016).

10. S. Homma, J.L. Thompson, M. Qian, S. Ye, M.R. Di Tullio, G.Y. Lip, D.L. Mann, R.L. Sacco, B. Levin, P.M. Pullicino, R.S. Freudenberger, J.R. Teerlink, S. Graham, J.P. Mohr, A.J. Labovitz, R. Buchsbaum, C.J. Estol, D.J. Lok, P. Ponikowski, and S.D. Anker. Quality of anticoagulation control in preventing adverse events in patients with heart failure in sinus rhythm: Warfarin versus Aspirin in Reduced Cardiac Ejection Fraction trial substudy. Circulation Heart failure. 8:504-509 (2015)

11. J.P. Higgins, S.G. Thompson, J.J. Deeks, and D.G. Altman. Measuring inconsistency in meta-analyses. BMJ (Clinical research ed). 327:557-560 (2003).

12. M. Egger, G. Davey Smith, M. Schneider, and C. Minder. Bias in meta-analysis detected by a simple, graphical test. BMJ (Clinical research ed). $315: 629-634$ (1997).

13. O.D. Lara, R.E. O'Cearbhaill, M.J. Smith, and M.E. Sutter. COVID-19 outcomes of patients with gynecologic cancer in New York City. (2020).

14. L.Y.W. Lee, J.B. Cazier, T. Starkey, C.D. Turnbull, R. Kerr, and G. Middleton. COVID-19 mortality in patients with cancer on chemotherapy or other anticancer treatments: a prospective cohort study. Lancet (London, England). 395:1919-1926 (2020).

15. J. Luo, H. Rizvi, and J.V. Egger. Impact of PD-1 Blockade on Severity of COVID-19 in Patients with Lung Cancers. 10:1121-1128 (2020).

16. D.J. Pinato, A. Zambelli, J. Aguilar-Company, and M. Bower. Clinical portrait of the SARS-CoV-2 epidemic in European cancer patients. (2020).

17. E.V. Robilotti, N.E. Babady, P.A. Mead, and T. Rolling. Determinants of COVID-19 disease severity in patients with cancer. 26:1218-1223 (2020).

18. B. Szabados, Y. Abu-Ghanem, M. Grant, J. Choy, A. Bex, and T. Powles. Clinical Characteristics and Outcome for Four SARS-CoV-2-infected Cancer Patients Treated with Immune Checkpoint Inhibitors. European urology. 78:276-280 (2020).

19. Q. Wu, Q. Chu, H. Zhang, B. Yang, X. He, Y. Zhong, X. Yuan, M.L.K. Chua, and C. Xie. Clinical outcomes of coronavirus disease 2019 (COVID-19) in cancer patients with prior exposure to immune checkpoint inhibitors. (2020).

20. C. Artigas, M. Lemort, F. Mestrez, T. Gil, and P. Flamen. COVID-19 Pneumonia Mimicking Immunotherapy-Induced Pneumonitis on 18F-FDG PET/CT in a Patient Under Treatment With Nivolumab. Clinical nuclear medicine. 45:e381-e382 (2020).

21. G. Bisogno, M. Provenzi, D. Zama, A. Tondo, C. Meazza, A. Colombini, F. Galaverna, F. Compagno, F. Carraro, R. De Santis, L. Meneghello, V. Baretta, and S. Cesaro. Clinical characteristics and outcome of SARS-CoV-2 infection in Italian pediatric oncology patients: a study from the Infectious Diseases Working Group of the AIEOP. Journal of the Pediatric Infectious Diseases Society(2020).

22. A.M. Di Giacomo, E. Gambale, S. Monterisi, M. Valente, and M. Maio. SARS-COV-2 infection in patients with cancer undergoing checkpoint blockade: Clinical course and outcome. European journal of cancer. 133:1-3 (2020).

23. A.E. Guerini, P. Borghetti, A.R. Filippi, M.L. Bonù, D. Tomasini, D. Greco, J. Imbrescia, G. Volpi, L. Triggiani, A. Borghesi, R. Maroldi, N. Pasinetti, M. Buglione, and S.M. Magrini. Differential Diagnosis and Clinical Management of a Case of COVID-19 in a Patient With Stage III Lung Cancer Treated With Radiochemotherapy and Durvalumab. Clinical lung cancer(2020).

24. C.M. Lovly. Rapidly fatal pneumonitis from immunotherapy and concurrent SARS-CoV-2 infection in a patient with newly diagnosed lung cancer. (2020).

25. C. Pinto, A. Berselli, L. Mangone, A. Damato, F. lachetta, M. Foracchia, F. Zanelli, E. Gervasi, A. Romagnani, G. Prati, S. Lui, F. Venturelli, M. Vicentini, and G. Besutti. SARS-CoV-2 Positive Hospitalized Cancer Patients during the Italian Outbreak: The Cohort Study in Reggio Emilia. 9:(2020). 
26. C. Rolfo, A.F. Cardona, A. Ruiz-Patiño, S. Ariza, L. Zatarain-Barron, L.E. Pino, L. Viola, A. Russo, L. Rojas, L. Ricaurte, and O. Arrieta. Atypical Skin Manifestations During Immune Checkpoint Blockage in Coronavirus Disease 2019-Infected Patients With Lung Cancer. Journal of thoracic oncology : official publication of the International Association for the Study of Lung Cancer(2020).

27. D. Trapani, A. Marra, and G. Curigliano. The experience on coronavirus disease 2019 and cancer from an oncology hub institution in Milan, Lombardy Region. European journal of cancer. 132:199-206 (2020).

28. R. Yarza, M. Bover, D. Paredes, F. López-López, D. Jara-Casas, A. Castelo-Loureiro, J. Baena, J.M. Mazarico, M.D. Folgueira, M. Meléndez-Carmona, A. Reyes, C. Lumbreras, L. Paz-Ares, C. Díaz-Pedroche, and C. Gómez-Martín. SARS-CoV-2 infection in cancer patients undergoing active treatment: analysis of clinical features and predictive factors for severe respiratory failure and death. European journal of cancer. 135:242-250 (2020).

29. E. Yekedüz, B. Dursun, G. Aydın, S.C. Yazgan, H.H. Öztürk, A. Azap, G. Utkan, and Y. Ürün. Clinical course of COVID-19 infection in elderly patient with melanoma on nivolumab. 26:1289-1294 (2020).

30. J.R. Brahmer, C.G. Drake, I. Wollner, J.D. Powderly, J. Picus, W.H. Sharfman, E. Stankevich, A. Pons, T.M. Salay, T.L. McMiller, M.M. Gilson, C. Wang, M. Selby, J.M. Taube, R. Anders, L. Chen, A.J. Korman, D.M. Pardoll, I. Lowy, and S.L. Topalian. Phase I study of single-agent anti-programmed death-1 (MDX$1106)$ in refractory solid tumors: safety, clinical activity, pharmacodynamics, and immunologic correlates. Journal of clinical oncology : official journal of the American Society of Clinical Oncology. 28:3167-3175 (2010).

31. S.J. Im, M. Hashimoto, M.Y. Gerner, J. Lee, H.T. Kissick, M.C. Burger, Q. Shan, J.S. Hale, J. Lee, T.H. Nasti, A.H. Sharpe, G.J. Freeman, R.N. Germain, H.I. Nakaya, H.H. Xue, and R. Ahmed. Defining CD8+ T cells that provide the proliferative burst after PD-1 therapy. Nature. 537:417-421 (2016).

32. A.C. Huang, M.A. Postow, R.J. Orlowski, R. Mick, B. Bengsch, S. Manne, W. Xu, S. Harmon, J.R. Giles, B. Wenz, M. Adamow, D. Kuk, K.S. Panageas, C. Carrera, P. Wong, F. Quagliarello, B. Wubbenhorst, K. D'Andrea, K.E. Pauken, R.S. Herati, R.P. Staupe, J.M. Schenkel, S. McGettigan, S. Kothari, S.M. George, R.H. Vonderheide, R.K. Amaravadi, G.C. Karakousis, L.M. Schuchter, X. Xu, K.L. Nathanson, J.D. Wolchok, T.C. Gangadhar, and E.J. Wherry. T-cell invigoration to tumour burden ratio associated with anti-PD-1 response. Nature. 545:60-65 (2017).

33. B.P. Fairfax, C.A. Taylor, R.A. Watson, I. Nassiri, S. Danielli, and H. Fang. Peripheral CD8(+) T cell characteristics associated with durable responses to immune checkpoint blockade in patients with metastatic melanoma. 26:193-199 (2020).

34. T.D. Wu, S. Madireddi, P.E. de Almeida, R. Banchereau, Y.J. Chen, A.S. Chitre, E.Y. Chiang, H. Iftikhar, W.E. O'Gorman, A. Au-Yeung, C. Takahashi, L.D. Goldstein, C. Poon, S. Keerthivasan, D.E. de Almeida Nagata, X. Du, H.M. Lee, K.L. Banta, S. Mariathasan, M. Das Thakur, M.A. Huseni, M. Ballinger, I. Estay, P. Caplazi, Z. Modrusan, L. Delamarre, I. Mellman, R. Bourgon, and J.L. Grogan. Peripheral T cell expansion predicts tumour infiltration and clinical response. Nature. 579:274-278 (2020).

35. I.L. Souza, Í. Fernandes, P. Taranto, A.C. Buzaid, and G. Schvartsman. Immune-related pneumonitis with nivolumab and ipilimumab during the coronavirus disease 2019 (COVID-19) pandemic. European journal of cancer. 135:147-149 (2020).

36. M. Kambojand K.A. Sepkowitz. Nosocomial infections in patients with cancer. The Lancet Oncology. 10:589-597 (2009).

37. J.Y. Li, X.F. Duan, L.P. Wang, Y.J. Xu, and L. Huang. Selective depletion of regulatory T cell subsets by docetaxel treatment in patients with nonsmall cell lung cancer. 2014:286170 (2014).

38. E.R. Longbottom, H.D. Torrance, H.C. Owen, P.C. Fragkou, C.J. Hinds, R.M. Pearse, and M.J. O'Dwyer. Features of Postoperative Immune Suppression Are Reversible With Interferon Gamma and Independent of Interleukin-6 Pathways. Annals of surgery. 264:370-377 (2016).

39. A. Sicaand M. Massarotti. Myeloid suppressor cells in cancer and autoimmunity. Journal of autoimmunity. 85:117-125 (2017).

40. T. Wang, Z. Du, F. Zhu, Z. Cao, Y. An, Y. Gao, and B. Jiang. Comorbidities and multi-organ injuries in the treatment of COVID-19. Lancet (London, England). 395:e52 (2020).

41. W. Liang, W. Guan, R. Chen, W. Wang, J. Li, K. Xu, C. Li, Q. Ai, W. Lu, H. Liang, S. Li, and J. He. Cancer patients in SARS-CoV-2 infection: a nationwide analysis in China. The Lancet Oncology. 21:335-337 (2020).

42. M. Bersanelli. Controversies about COVID-19 and anticancer treatment with immune checkpoint inhibitors. Immunotherapy. 12:269-273 (2020).

43. J. Choiand S.Y. Lee. Clinical Characteristics and Treatment of Immune-Related Adverse Events of Immune Checkpoint Inhibitors. 20:e9 (2020).

44. D.Y. Wang, J.E. Salem, J.V. Cohen, S. Chandra, C. Menzer, F. Ye, S. Zhao, S. Das, K.E. Beckermann, L. Ha, W.K. Rathmell, K.K. Ancell, J.M. Balko, C. Bowman, E.J. Davis, D.D. Chism, L. Horn, G.V. Long, M.S. Carlino, B. Lebrun-Vignes, Z. Eroglu, J.C. Hassel, A.M. Menzies, J.A. Sosman, R.J. Sullivan, J.J. Moslehi, and D.B. Johnson. Fatal Toxic Effects Associated With Immune Checkpoint Inhibitors: A Systematic Review and Meta-analysis. JAMA oncology. 4:17211728 (2018).

45. S.J. Rotz, D. Leino, S. Szabo, J.L. Mangino, B.K. Turpin, and J.G. Pressey. Severe cytokine release syndrome in a patient receiving PD-1-directed therapy. Pediatric blood \& cancer. 64:(2017).

46. C. Chen, X.R. Zhang, Z.Y. Ju, and W.F. He. [Advances in the research of mechanism and related immunotherapy on the cytokine storm induced by coronavirus disease 2019]. Zhonghua shao shang za zhi = Zhonghua shaoshang zazhi = Chinese journal of burns. 36:471-475 (2020).

47. Z. Xu, L. Shi, Y. Wang, J. Zhang, L. Huang, C. Zhang, S. Liu, P. Zhao, H. Liu, L. Zhu, Y. Tai, C. Bai, T. Gao, J. Song, P. Xia, J. Dong, J. Zhao, and F.S. Wang. Pathological findings of COVID-19 associated with acute respiratory distress syndrome. The Lancet Respiratory medicine. 8:420-422 (2020).

48. A. Friedlaender, C. Kim, and A. Addeo. Rethinking the Optimal Duration of Immune Checkpoint Inhibitors in Non-small Cell Lung Cancer Throughout the COVID-19 Pandemic. Frontiers in oncology. 10:862 (2020).

49. Z. Wang, J. Wang, and J. He. Active and Effective Measures for the Care of Patients With Cancer During the COVID-19 Spread in China. JAMA oncology(2020).

50. S. Aeppli, E.I. Eboulet, T. Eisen, B. Escudier, S. Fischer, J. Larkin, and V. Gruenwald. Impact of COVID-19 pandemic on treatment patterns in metastatic clear cell renal cell carcinoma. 5:(2020). 
51. K. de Joode, D.W. Dumoulin, V. Engelen, H.J. Bloemendal, M. Verheij, H.W.M. van Laarhoven, I.H. Dingemans, A.C. Dingemans, and A.A.M. van der Veldt. Impact of the coronavirus disease 2019 pandemic on cancer treatment: the patients' perspective. European journal of cancer. 136:132-139 (2020).

52. T.A. Fox, E. Troy-Barnes, A.A. Kirkwood, W.Y. Chan, and J.W. Day. Clinical outcomes and risk factors for severe COVID-19 in patients with haematological disorders receiving chemo- or immunotherapy. (2020).

\section{Table}

Table 1 is also available as a PDF in the Supplementary Files. 


\begin{tabular}{|c|c|c|c|c|c|c|}
\hline \multirow{19}{*}{$\begin{array}{l}\text { Table1.Characteristics } \\
\text { of the Included } \\
\text { Studies. }\end{array}$} & Quality & 8 & 5 & 8 & 6 & 6 \\
\hline & $\begin{array}{l}\text { Included in } \\
\text { the meta- } \\
\text { analysis }\end{array}$ & Yes & Yes & Yes & $Y_{e s}^{a}$ & Yes \\
\hline & Outcome & $\begin{array}{l}\text { Mortality and } \\
\text { severity }\end{array}$ & $\begin{array}{l}\text { Hospitalization, } \\
\text { severity and } \\
\text { mortality }\end{array}$ & Mortality & $\begin{array}{l}\text { Hospitalization, } \\
\text { severity and } \\
\text { mortality }\end{array}$ & Mortality \\
\hline & $\begin{array}{l}\text { Cancer } \\
\text { stage }\end{array}$ & $\begin{array}{l}\text { Metastatic } \\
\text { cancer(17) }\end{array}$ & $\mathrm{I} / \mathrm{II}(41)$ & $\begin{array}{l}\text { Primary tumour } \\
\text { localised(149) }\end{array}$ & $\begin{array}{l}\text { Metastatic or active } \\
\text { lung cancer(55) }\end{array}$ & Non-advanced(539) \\
\hline & & & III/IV(69)" & $\begin{array}{l}\text { Primary tumour } \\
\text { locally advanced(78) }\end{array}$ & & $\begin{array}{l}\text { Advanced(351) } \\
"\end{array}$ \\
\hline & & & & Metastatic(347) & & \\
\hline & & & & Remission(21) & & \\
\hline & & & & $\begin{array}{l}\text { No } \\
\text { information(205)" }\end{array}$ & & \\
\hline & $\begin{array}{l}\text { Cancer } \\
\text { type }\end{array}$ & $\begin{array}{l}\text { Breast cancer(11) } \\
\text { Blood cancer(9) } \\
\text { Cervix cancer(6) } \\
\text { Esophagus } \\
\text { cancer(6) } \\
\text { Gastrointestinal } \\
\text { cancer(13) } \\
\text { Lung cancer(22) } \\
\text { Thyroid } \\
\text { cancer(11) }\end{array}$ & $\begin{array}{l}\text { Gynecologic } \\
\text { Cancer(121) }\end{array}$ & $\begin{array}{l}\text { Breast(102) } \\
\text { Lip, oral cavity,and } \\
\text { pharynx(27) } \\
\text { Central nervous } \\
\text { system(15) } \\
\text { Digestive } \\
\text { organs(150) } \\
\text { Female genital } \\
\text { organs(45) } \\
\text { Lymphoma(60) } \\
\text { Melanoma (skin) } \\
\text { (27) } \\
\text { Male genital } \\
\text { organs(78) } \\
\text { Respiratory and } \\
\text { Intrathoracic } \\
\text { organs(90) } \\
\text { Urinary tract(50) } \\
\text { Other } \\
\text { haematological(109) } \\
\text { Other or } \\
\text { unspecified(47) }\end{array}$ & Lung cancers(69) & $\begin{array}{l}\text { Breast(162) } \\
\text { Genito-Urinary(132) } \\
\text { Gastrointestinal(105) } \\
\text { Gynaecological(41) } \\
\text { Gastro- } \\
\text { esophageal(40) } \\
\text { Hepatobiliary(45) } \\
\text { Head and Neck(29) } \\
\text { Lung(119) } \\
\text { Skin(28) } \\
\text { Other(52) } \\
\text { Haematological } \\
\text { Malignancies(137) }\end{array}$ \\
\hline & $\begin{array}{l}\text { Anti-tumor } \\
\text { Treatment }\end{array}$ & $\begin{array}{l}\text { Chemotherapy(17) } \\
\text { Immunotherapy(6) } \\
\text { Radiotherapy(13) } \\
\text { Surgery(8) } \\
\text { Targeted } \\
\text { therapy(4) }\end{array}$ & $\begin{array}{l}\text { Surgery }(11) \\
\text { Chemotherapy(35) } \\
\text { Immunotherapy(8) } \\
\text { Targeted } \\
\text { therapy(13) } \\
\text { Hormone } \\
\text { therapy(9) } \\
\text { Radiotherapy(9) }\end{array}$ & $\begin{array}{l}\text { Chemotherapy(281) } \\
\text { Hormone } \\
\text { therapy(64) } \\
\text { Immunotherapy(44) } \\
\text { Radiotherapy(76) } \\
\text { Surgery(29) } \\
\text { Targeted } \\
\text { treatment(72) } \\
\text { Other(60) } \\
\text { None(272) }\end{array}$ & Immunotherapy(20) & $\begin{array}{l}\text { Chemotherapy(206) } \\
\text { Endocrine } \\
\text { therapy(92) } \\
\text { Immunotherapy }(56) \\
\text { Targeted therapy }(93)\end{array}$ \\
\hline & $\begin{array}{l}\text { Treatment } \\
\text { interval } \\
\text { before } \\
\text { Diagnosis }\end{array}$ & Within 40 days & NR & Within 4 weeks & $\begin{array}{l}\text { Within } 6 \text { weeks } \\
(n=20) \\
\text { Within } 6 \text { months } \\
(n=30) \\
\text { Ever }(n=40)\end{array}$ & Within 4 weeks \\
\hline & $\begin{array}{l}\text { No. of pts } \\
\text { with ICl }\end{array}$ & 6 & 8 & 44 & 40 & 56 \\
\hline & No. of pts & 641 & 121 & 800 & 69 & 890 \\
\hline & Male & $302(47 \%)$ & NR & $449(56 \%)$ & $33(48 \%)$ & $503(56.5 \%)$ \\
\hline & Age & $\begin{array}{l}\text { Male median: } 64 \\
\text { Female } \\
\text { median: } 63.5\end{array}$ & 64(IQR 51-73) & 69 (range $59-76$ ) & 69 (range 31-91) & 68(range 21-99) \\
\hline & Study type & $\begin{array}{l}\text { Multi-center } \\
\text { prospective } \\
\text { cohort }\end{array}$ & $\begin{array}{l}\text { Multi-center } \\
\text { retrospective } \\
\text { cohort }\end{array}$ & $\begin{array}{l}\text { Multi-center } \\
\text { prospective cohort }\end{array}$ & $\begin{array}{l}\text { Single-center } \\
\text { retrospective cohort }\end{array}$ & $\begin{array}{l}\text { Multi-center } \\
\text { retrospective } \\
\text { cohort }\end{array}$ \\
\hline & $\begin{array}{l}\text { Date of } \\
\text { COVID-19 } \\
\text { diagnosis }\end{array}$ & $\begin{array}{l}\text { January } 1 \text {, to } \\
\text { February } 24,2020\end{array}$ & $\begin{array}{l}\text { March 1, to April } \\
22,2020\end{array}$ & $\begin{array}{l}\text { March } 18 \text {, to April } \\
26,2020\end{array}$ & $\begin{array}{l}\text { March } 12 \text {, to April } \\
13,2020\end{array}$ & $\begin{array}{l}\text { February } 26 \text { and May } \\
7,2020\end{array}$ \\
\hline & Country & China & The United States & The United Kingdom & The United States & $\begin{array}{l}\text { The United Kingdom } \\
(n=218) \\
\text { Italy }(n=343) \\
\text { Spain }(n=323) \\
\text { Germany }(n=6)\end{array}$ \\
\hline & First author & Dai et al & Lara et al & Lee et al & Luo et al & Pinato et al \\
\hline
\end{tabular}




\begin{tabular}{|c|c|c|c|c|c|c|c|}
\hline \multirow{15}{*}{$\begin{array}{l}\text { Table } 1 \\
\text { (Continued) }\end{array}$} & Quality & 5 & 5 & 5 & & & \\
\hline & $\begin{array}{l}\text { Included } \\
\text { in the } \\
\text { meta- } \\
\text { analysis }\end{array}$ & Yes & Yes & Yes & No & No & No \\
\hline & Outcome & $\begin{array}{l}\text { Hospitalization and } \\
\text { severity }\end{array}$ & $\begin{array}{l}\text { Hospitalization, } \\
\text { severity and } \\
\text { mortality }\end{array}$ & $\begin{array}{l}\text { Severity and } \\
\text { mortality }\end{array}$ & Hospitalization & $\begin{array}{l}\text { Severity and } \\
\text { mortality }\end{array}$ & $\begin{array}{l}\text { Hospitalizatic } \\
\text { severity and } \\
\text { mortality }\end{array}$ \\
\hline & $\begin{array}{l}\text { Cancer } \\
\text { stage }\end{array}$ & Metastatic(238) & $\operatorname{IV}(4)$ & NR & Metastatic(1) & NR & $\begin{array}{l}\text { "Metastatic(1 } \\
\text { Locally } \\
\text { advanced(1)" }\end{array}$ \\
\hline & $\begin{array}{l}\text { Cancer } \\
\text { type }\end{array}$ & $\begin{array}{l}\text { Breast(86) } \\
\text { Colorectal(37) } \\
\text { Hematologic(24) } \\
\text { Lung(35) } \\
\text { Prostate(26) } \\
\text { Other(137) }\end{array}$ & $\begin{array}{l}\text { Renal cell } \\
\text { carcinoma(2) } \\
\text { Urothelial } \\
\text { carcinoma(2) }\end{array}$ & $\begin{array}{l}\text { Cervical squamous } \\
\text { cancer(1) } \\
\text { Colorectal } \\
\text { Adenocarcinoma(1) } \\
\text { Endometrial } \\
\text { cancer(1) } \\
\text { Hepatocellular } \\
\text { carcinoma(1) } \\
\text { Lung cancers(7) }\end{array}$ & $\begin{array}{l}\text { Renal cell } \\
\text { carcinoma(1) }\end{array}$ & $\begin{array}{l}\text { Leukemia(16) } \\
\text { Lymphoma(3) } \\
\text { Ewing sarcoma(2) } \\
\text { Hepatoblastoma(2) } \\
\text { Other(6) }\end{array}$ & Melanoma(2) \\
\hline & $\begin{array}{l}\text { Anti- } \\
\text { tumor } \\
\text { Treatment }\end{array}$ & Immunotherapy(31) & Immunotherapy(4) & Immunotherapy(11) & Immunotherapy(1) & $\begin{array}{l}\text { Chemotherapy(25) } \\
\text { Allogeneic stem } \\
\text { cell transplant(3) } \\
\text { Immunotherapy(1) }\end{array}$ & Immunothera \\
\hline & $\begin{array}{l}\text { Treatment } \\
\text { interval } \\
\text { before } \\
\text { Diagnosis }\end{array}$ & Within 90 days & Within 90 days & Within 50 days & $\begin{array}{l}4 \text { months before } \\
\text { dignosis }\end{array}$ & NR & $\begin{array}{l}8 \text { days before } \\
\text { dignosis }\end{array}$ \\
\hline & $\begin{array}{l}\text { No. of pts } \\
\text { with ICl }\end{array}$ & 31 & 4 & 11 & 1 & 1 & 2 \\
\hline & No. of pts & 423 & 4 & 11 & 1 & 29 & 2 \\
\hline & Male & $212(50 \%)$ & $4(100 \%)$ & $8(73 \%)$ & $1(100 \%)$ & $8(13 \%)$ & $1(50 \%)$ \\
\hline & Age & $\begin{array}{l}416 \text { pts }>18(98 \%) \\
234 \text { pts }>60(56 \%)\end{array}$ & 67(range 52-72) & 66(range 29-73) & 51 & 7(range 0-16) & 51 and 74 \\
\hline & $\begin{array}{l}\text { Study } \\
\text { type }\end{array}$ & $\begin{array}{l}\text { Single-center } \\
\text { retrospective cohort }\end{array}$ & $\begin{array}{l}\text { Single-center } \\
\text { prospective } \\
\text { case series }\end{array}$ & Case series & Case report & $\begin{array}{l}\text { Multi-center } \\
\text { retrospective } \\
\text { cohort }\end{array}$ & Case series \\
\hline & $\begin{array}{l}\text { Data of } \\
\text { COVID-19 } \\
\text { diagnosis }\end{array}$ & $\begin{array}{l}\text { March 10,to April 7, } \\
2020\end{array}$ & $\begin{array}{l}\text { February } 1 \text { and } \\
\text { April 27, } 2020\end{array}$ & $\begin{array}{l}\text { January 9,to March } \\
20,2020\end{array}$ & NR & $\begin{array}{l}\text { February } 23 \text {, to } \\
\text { April } 24,2020\end{array}$ & $\begin{array}{l}\text { March } 16 \text { anc } \\
\text { March 25, 20: }\end{array}$ \\
\hline & Country & The United States & $\begin{array}{l}\text { The United } \\
\text { Kingdom }\end{array}$ & China & Belgium & Italy & Italy \\
\hline & $\begin{array}{l}\text { First } \\
\text { author }\end{array}$ & Robilotti et al & Szabados et al & Wu et al & Artigas et al & Bisogno et al & Giacomo et a \\
\hline
\end{tabular}




\begin{tabular}{|c|c|c|c|c|c|c|}
\hline \multirow{15}{*}{$\begin{array}{l}\text { Table } 1 \\
\text { (Continued) }\end{array}$} & \multicolumn{6}{|l|}{ Quality } \\
\hline & $\begin{array}{l}\text { Included } \\
\text { in the } \\
\text { meta- } \\
\text { analysis }\end{array}$ & No & No & No & $\mathrm{No}^{\mathrm{b}}$ & No \\
\hline & Outcome & $\begin{array}{l}\text { Hospitalization, } \\
\text { severity and } \\
\text { mortality }\end{array}$ & $\begin{array}{l}\text { Hospitalization, severity and } \\
\text { mortality }\end{array}$ & $\begin{array}{l}\text { Hospitalization, } \\
\text { severity and } \\
\text { mortality }\end{array}$ & $\begin{array}{l}\text { Severity and } \\
\text { mortality }\end{array}$ & $\begin{array}{l}\text { Hospitalization, } \\
\text { severity and } \\
\text { mortality }\end{array}$ \\
\hline & $\begin{array}{l}\text { Cancer } \\
\text { stage }\end{array}$ & NR & $\mathrm{IV}(2)$ & Metastatic(5) & Metastatic(11) & metastatic(1) \\
\hline & $\begin{array}{l}\text { Cancer } \\
\text { type }\end{array}$ & $\begin{array}{l}\text { Bladder(12) } \\
\text { Breast(27) } \\
\text { Colorectal(25) } \\
\text { Kidney(4) } \\
\text { Lung(9) } \\
\text { Prostate(30) } \\
\text { Stomach(4) } \\
\text { Thyroid(4) } \\
\text { Uterus(3) } \\
\text { Mesothelioma(1) } \\
\text { Other(19) }\end{array}$ & Lung cancer (2) & $\begin{array}{l}\text { Breast(1) } \\
\text { Gastric(1) } \\
\text { Head and neck(1) } \\
\text { Leukaemia(1) } \\
\text { Lung(1) } \\
\text { Melanoma(1) } \\
\text { Urothelial(2) } \\
\text { NET(1) }\end{array}$ & $\begin{array}{l}\text { Central nervous } \\
\text { system(1) } \\
\text { Kidney(1) } \\
\text { Lung(17) } \\
\text { Colorectal(10) } \\
\text { Upper GI cancer(6) } \\
\text { Bladder(3) } \\
\text { Breast(10) } \\
\text { Gynaecologic(2) } \\
\text { Prostate(5) } \\
\text { Thyroid(3) } \\
\text { Head and Neck(4) } \\
\text { Sarcoma(1) } \\
\text { Cancer of } \\
\text { unknown(3) }\end{array}$ & Melanoma(1) \\
\hline & $\begin{array}{l}\text { Anti- } \\
\text { tumor } \\
\text { Treatment }\end{array}$ & $\begin{array}{l}\text { Antiangiogenic } \\
\text { therapy }(1) \\
\text { Chemotherapy }(12) \\
\text { Immunotherapy }(1) \\
\text { Hormone } \\
\text { therapy }(1)\end{array}$ & $\begin{array}{l}\text { Stereotactic } \\
\text { radiosurgery+immunotherapy }(1) \\
\text { Chemotherapy+immunotherapy }(1)\end{array}$ & $\begin{array}{l}\text { Chemotherapy(3) } \\
\text { Immunotherapy(2) } \\
\text { Targeted } \\
\text { treatment(2) }\end{array}$ & $\begin{array}{l}\text { Chemotherapy }(36) \\
\text { Endocrine }(10) \\
\text { Immunotherapy }(8) \\
\text { Target therapy }(7)\end{array}$ & Immunotherapy(1) \\
\hline & $\begin{array}{l}\text { Treatment } \\
\text { interval } \\
\text { before } \\
\text { Diagnosis }\end{array}$ & Within 60 days & NR & Within 14 days & Within 4 weeks & $\begin{array}{l}4 \text { days before } \\
\text { dignosis }\end{array}$ \\
\hline & $\begin{array}{l}\text { No. of pts } \\
\text { with ICl }\end{array}$ & 1 & 2 & 2 & 8 & 1 \\
\hline & No. of pts & 1226 & 2 & 9 & 63 & 1 \\
\hline & Male & $733(60 \%)$ & $1(50 \%)$ & $7(78 \%)$ & $34(54 \%)$ & $0(0 \%)$ \\
\hline & Age & 73(range 23-100) & 58 and 62 & 68(range 42-79) & $\begin{array}{l}66(95 \% \mathrm{Cl} 63.4- \\
68.8)\end{array}$ & 75 \\
\hline & $\begin{array}{l}\text { Study } \\
\text { type }\end{array}$ & $\begin{array}{l}\text { Single-center } \\
\text { retrospective } \\
\text { cohort }\end{array}$ & Case series & $\begin{array}{l}\text { Single-center } \\
\text { retrospective case } \\
\text { series }\end{array}$ & $\begin{array}{l}\text { Single-center } \\
\text { retrospective } \\
\text { cohort }\end{array}$ & Case report \\
\hline & $\begin{array}{l}\text { Data of } \\
\text { COVID-19 } \\
\text { diagnosis }\end{array}$ & $\begin{array}{l}\text { February } 1 \text {, to April } \\
3,2020\end{array}$ & March 20 and March 24, 2020 & $\begin{array}{l}\text { February } 1 \text {, to April } \\
2,2020\end{array}$ & $\begin{array}{l}\text { March 9, to April } \\
19,2020\end{array}$ & March 202020 \\
\hline & Country & Italy & The United States & Italy & Spain & Turkey \\
\hline & $\begin{array}{l}\text { First } \\
\text { author }\end{array}$ & Pinto et al & Rolfo et al & Trapani et al & Yarza et al & Yekeduz et al \\
\hline
\end{tabular}

\section{Figures}




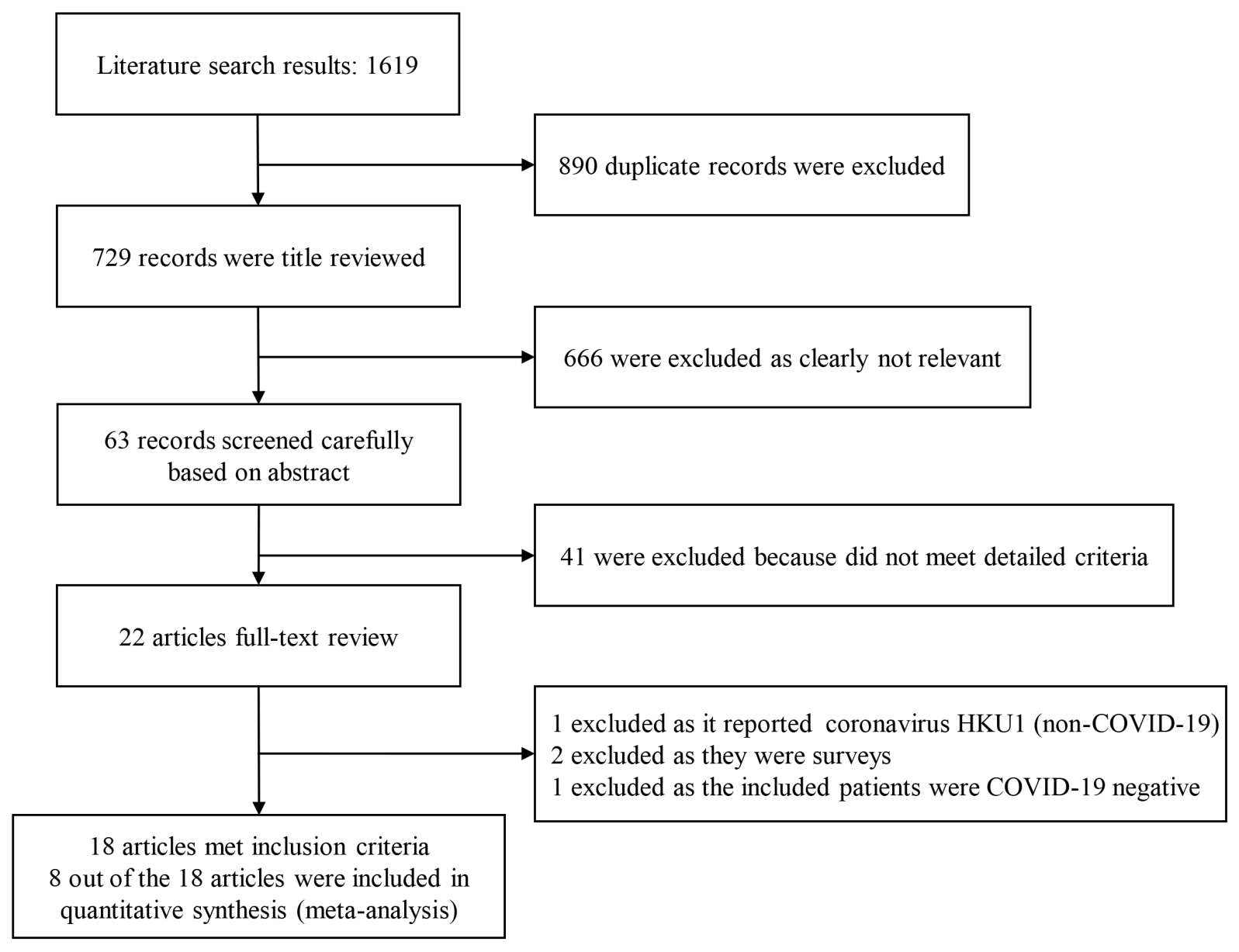

Figure 1

Flow chart for study selection. 
subgroup = Hospitalization

Lara et al

Luo et al

Robilotti et al

Szabados et al

Fixed effect model

Random effects model

Heterogeneity: $I^{2}=0 \%, \tau^{2}=0, p=0.75$

subgroup $=$ Severe disease

Dai et al

Lara et al

Luo et al

Robilotti et al

Szabados et al

Wu et al

Fixed effect model

58

$15 \quad 20$

$20 \quad 31$

24

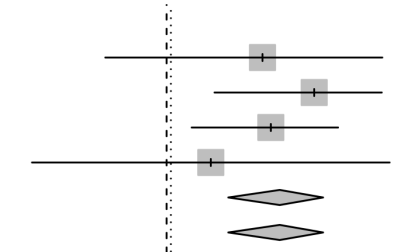

Random effects mode

Heterogeneity: $I^{2}=0 \%, \tau^{2}=0, p=0.44$

subgroup $=$ Mortality

Dai et al

Lara et al

Lee et al

Luo et al

Pinato et al

Szabados et al

Wu et al

Fixed effect model

Random effects model

Heterogeneity: $I^{2}=0 \%, \tau^{2}=0, p=0.82$

Fixed effect model

290

Random effects model

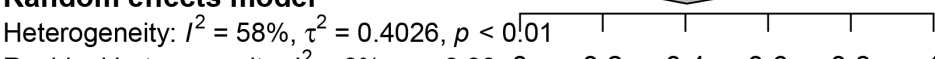

Residual heterogeneity: $I^{2}=0 \%, p=\begin{array}{lllllll}0.83 & 0 & 0.2 & 0.4 & 0.6 & 0.8 & 1\end{array}$
$0.62[0.24 ; 0.91]$

$0.75[0.51 ; 0.91]$

$0.65[0.45 ; 0.81]$

$0.50[0.07 ; 0.93]$

$0.67[0.54 ; 0.77]$

$0.67[0.54 ; 0.77]$

$0.67 \quad[0.22 ; 0.96]$

$0.38[0.09 ; 0.76]$

$0.32[0.13 ; 0.57]$

$0.39[0.22 ; 0.58]$

$0.25[0.01 ; 0.81]$

$0.64[0.31 ; 0.89]$

$0.42[0.31 ; 0.53]$

$0.42[0.31 ; 0.53]$

$0.33[0.04 ; 0.78]$

$0.38[0.09 ; 0.76]$

$0.23[0.11 ; 0.38]$

$0.16[0.03 ; 0.40]$

0.30 [0.19;0.44]

$0.00[0.00 ; 0.60]$

$0.36[0.11 ; 0.69]$

$0.26[0.20 ; 0.34]$

$0.26[0.20 ; 0.34]$

$0.39[0.34 ; 0.45]$

$0.40[0.31 ; 0.51]$

Figure 2

Pooled prognosis of COVID-19-infected patients with prior exposure to ICl. ICl: immune checkpoint inhibitors; OR: odds ratio; Cl: confidence interval. 


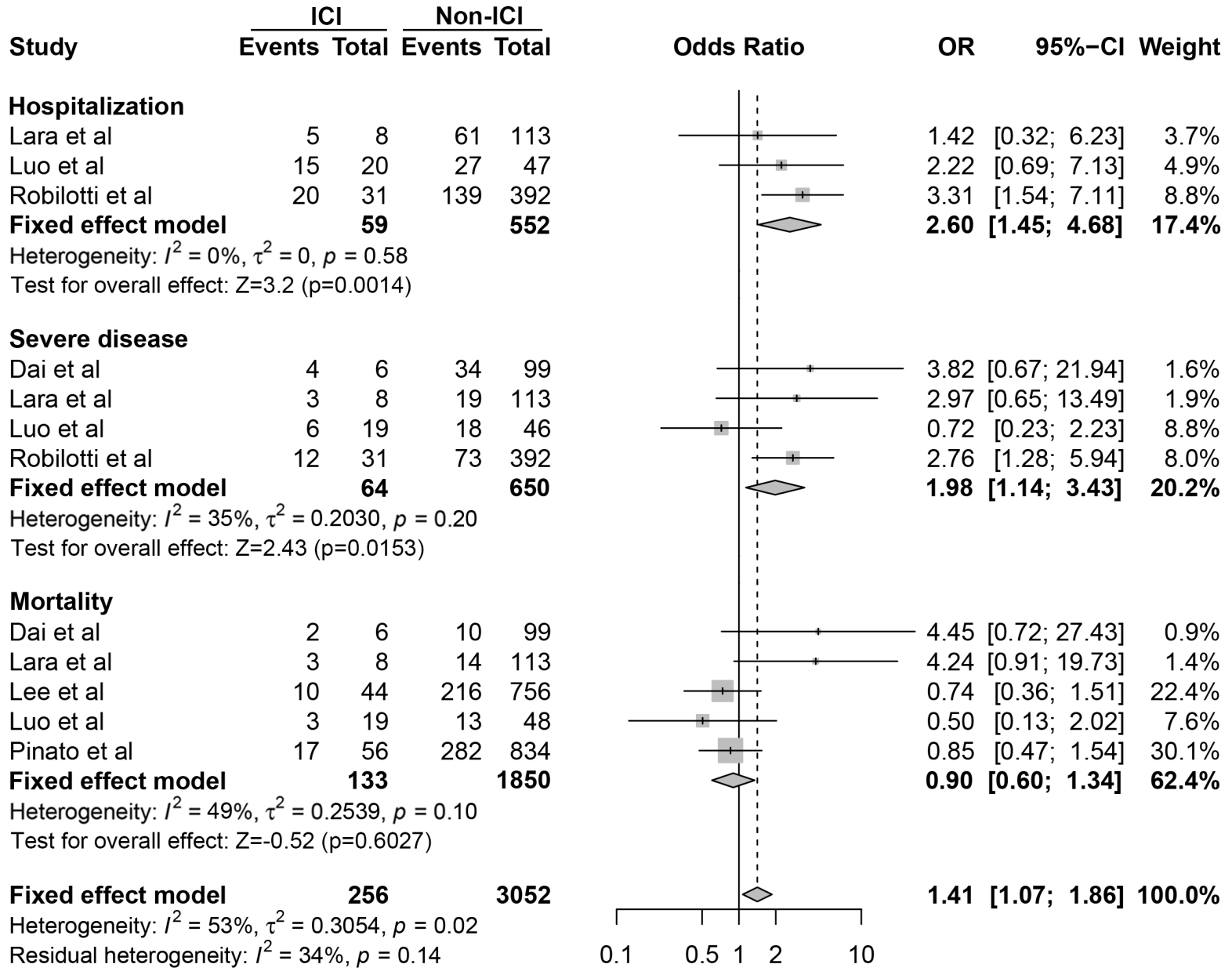

Figure 3

Pooled prognosis of COVID-19 infection compared between patients with prior ICI treatment and those without. ICl: immune checkpoint inhibitors; OR: odds ratio; $\mathrm{Cl}$ : confidence interval. 


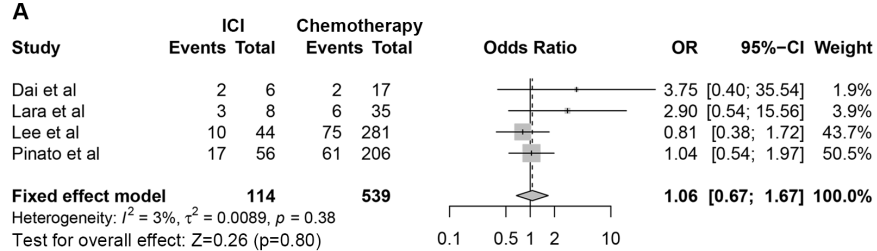

Test for overall effect: $z=0.0089, p=0.38$
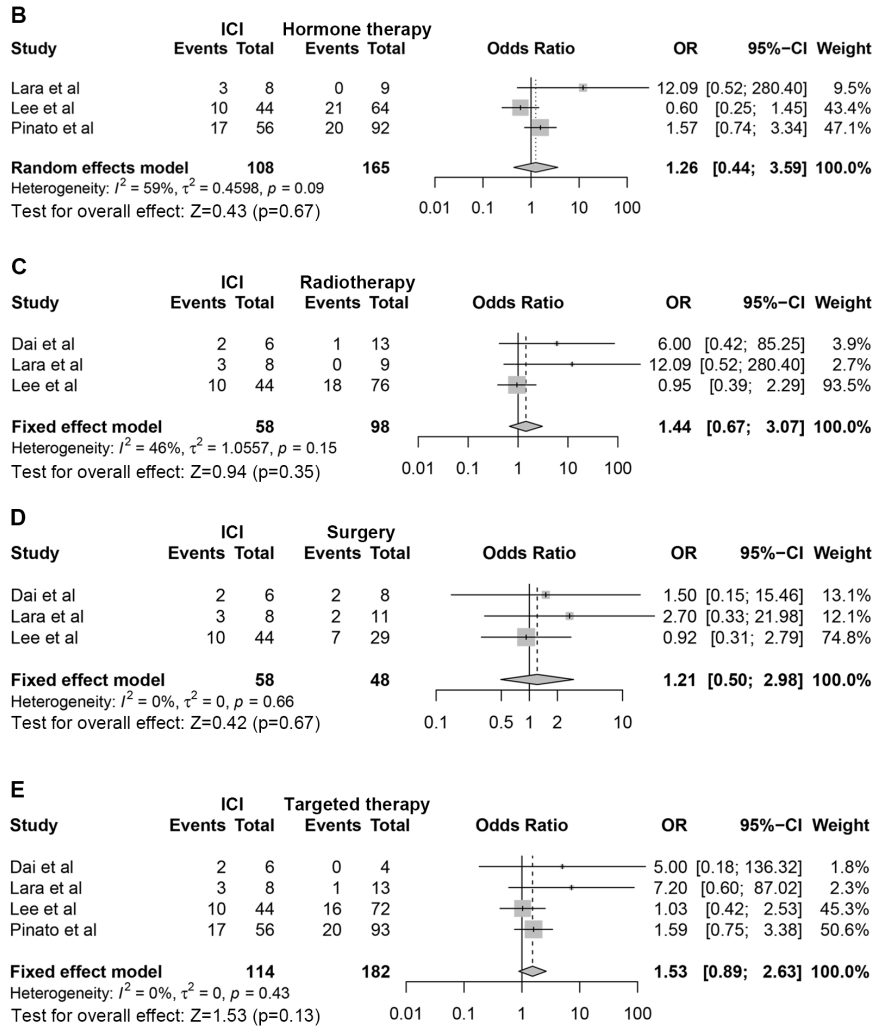

\section{Figure 4}

Pooled mortality of COVID-19 infection compared between patients with prior ICI treatment and those with chemotherapy $(A, p=0.80)$, hormone therapy $(B, p=$ $0.67)$, radiotherapy $(C, p=0.35)$, surgery $(D, p=0.67)$, or targeted therapy $(E, p=0.13)$. ICl: immune checkpoint inhibitors; OR: odds ratio; $C l$ : confidence interval.

A

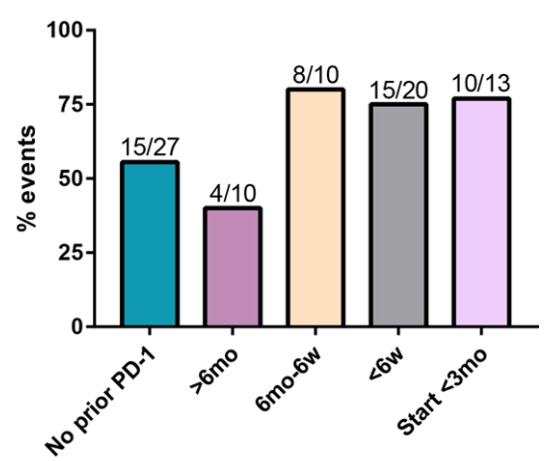

B

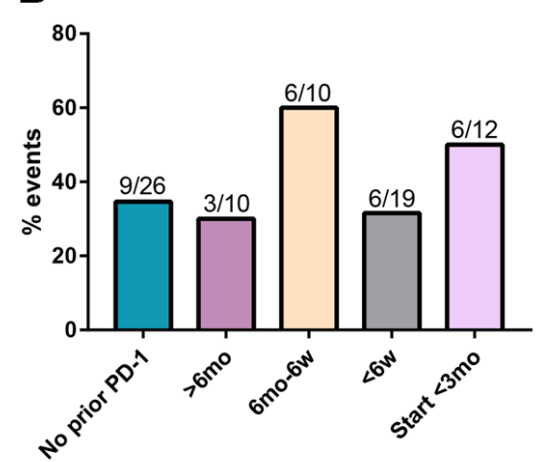

C Mortality

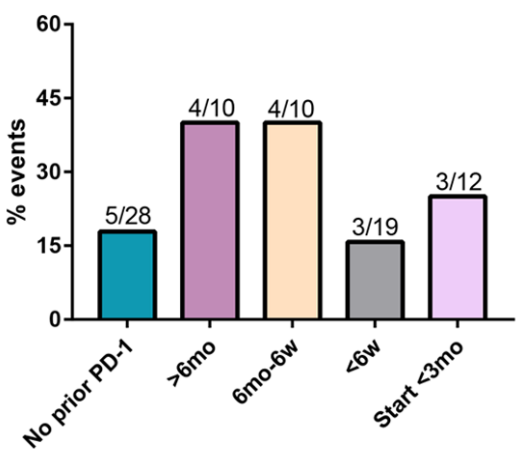

\section{Figure 5}

Impact of prior PD-1 exposure on the prognosis of COVID-19 in patients with lung cancer. Data were extracted from a previous study (15) , and patients was redistributed into five groups: no prior PD-1, interval $>6$ months ( $>6 \mathrm{mo})$, interval between 6 months and 6 weeks $(6 \mathrm{mo}-6 \mathrm{w})$, interval $<6 \mathrm{weeks}(<6 \mathrm{w})$ and initial dose within 3 months (start $<3 \mathrm{mo})$. (A) Rate of hospitalization compared between no prior PD-1 and $>6 \mathrm{mo}(p=0.48), 6 \mathrm{mo}-6 \mathrm{w}(\mathrm{p}=026)$, $<6 \mathrm{w}(\mathrm{p}=0.17)$, and start $<3 \mathrm{mo}(\mathrm{p}=0.30)$. (B) Rate of severe disease compared between no prior PD-1 and $>6 \mathrm{mo}(\mathrm{p}=1.00), 6 \mathrm{mo}-6 \mathrm{w}(\mathrm{p}=0.26),<6 \mathrm{w}(\mathrm{p}=0.38)$, and start $<3 \mathrm{mo}$ $(p=0.48)$. (C) Rate of death compared between no prior PD-1 and $>6 \mathrm{mo}(p=0.24), 6$ mo-6 w $(p=0.24),<6 \mathrm{w}(p=1.00)$, and start $<3$ mo $(p=0.68)$. 


\section{Supplementary Files}

This is a list of supplementary files associated with this preprint. Click to download.

- FigureS1.tif

- Table1.pdf 